\title{
EFFECT OF CYCLOPLEGIA ON BLUR PERCEPTION THRESHOLDS AS MEASURED BY SOURCE METHOD
}

\author{
Anete Petrova\#, Žanete Lulle, Pēteris Cikmačs, and Evita Kassaliete \\ Department of Optometry and Vision Science, Faculty of Physics and Mathematics, University of Latvia, \\ 1 Jelgavas Str., Rìga, LV-1004, LATVIA \\ \# Corresponding author, anete.petrova@lu.lv
}

Communicated by Ivars Lācis

\begin{abstract}
One of the advantages of a source method over observer method in blur perception measurements is better control of a stimulus blur level, which is achieved with computerised image processing unlike the observer method that requires optical defocusing of the observer. The aim of this study was to determine if paralysation of accommodation has effect on blur perception thresholds, thereby evaluating its necessity in such experiments. Blur perception thresholds (just noticeable blur, clear image, recognition, and non-resolvable blur thresholds) were evaluated with (using cycloplegia) and without paralysed accommodation to determine effect on blur perception. A computerised low-pass spatial frequency filter was used to process images of Landolt rings and gradually increase the blur level from the stage of clear image to the stage of unrecognisable orientation of Landolt ring opening. Ascending and descending psychophysical methods were used to evaluate the previously mentioned blur perception thresholds. Results for 10 participants revealed no significant effect of cycloplegia on any of the determined blur perception thresholds. Therefore, it may be considered that blur perception measurements with source method can be done without cycloplegia.
\end{abstract}

Key words: blur perception, blur adaptation, source blurring method, cycloplegia, Gaussian blur filter.

\section{INTRODUCTION}

Various blur perception thresholds are defined in order to broaden the fundamental knowledge of human blur perception. An observer does not notice any deterioration of the image when its quality is gradually decreased till the threshold of just noticeable blur is achieved (Ciuffreda et al., 2006). This threshold of blur detection corresponds to onehalf of depth-of-focus of the eye, which is a measure of dioptrical change of vergence resulting in perceptible focusing error (Atchison et al., 1997; Wang and Ciuffreda, 2005a). The blur discrimination threshold is the minimal blur level increment to perceive a change of blur (Wang and Ciuffreda, 2005a; 2005b; Cufflin, Manowska and Mallen, 2007). Atchison and colleagues (2005) have defined other complementary blur perception criterion - just troublesome blur at which observer becomes troubled by the image quality decrement. The criterion of "non-resolvable blur" developed by Ciuffreda and colleagues (2006) refers to the blur amount that do not allow recognizing and reading of a text or a letter. A similar definition was proposed by Atchison and colleagues (2005) with criterion "just objectionable blur".
Each blur perception threshold can be measured using either observer or source method (Smith et al., 1989). Using the source method an observer is adequately focused while the quality of stimulus is lowered using computerised processing of image or other methods that are applied only for stimulus. Using the observer method, stimuli are not affected but the observer is blurred with insufficient vision correction (for ametropes), additional ophthalmic lenses (for emmetropes) or light scattering filters. Dehnert et al. (2011) showed that results obtained with both methods are mutually comparable, while source methods have significant advantages over observer methods, such as ease and speed of blur level replacement, better control of the blur level, as observer eye squinting cannot affect image quality (Jacobs et al. 1989). Jacobs et al. (1989) also mentioned the unnecessity of accommodation control as an advantage of source methods. However, other studies have linked blur adaptation with changes of accommodation. For example, Vera-Diaz et al. (2004) demonstrated increase of accommodation response for myopes after 3 minutes of exposure to blurred image both at near (mean $-0.29 \mathrm{D}$ at $0.33 \mathrm{~m}$ ) and far distances (mean $-0.19 \mathrm{D}$ at $4 \mathrm{~m}$ ). Le et al. (2010) did not observe significant change of accommodation response af- 
ter a 5-min blur adaptation period, but noticed an increase in accommodative variability (standard deviation of accommodative responses for subject) for both myopes and emmetropes. In contrast, other studies (Vera-Diaz et al., 2004; Cufflin et al., 2007) observed that a 45-min long blur adaptation period did not change steady-state accommodative responses or the accommodative stimulus-response function gradient of both emmetropes and myopes. However, it was observed (Cufflin and Mallen, 2008) that adaptation to defocus caused increased accommodation for a dynamic target, and subsequently increased the response time and phase lag of emmetropes and myopes.

The aim of this study was to determine if accommodation control is mandatory for blur perception studies using the source blurring method. In this study, just noticeable blur, clear image, recognition, and non-resolvable blur thresholds were compared with and without accommodation paralysation (cycloplegia) to determine the effect of accommodation on blur perception thresholds.

\section{MATERIALS AND METHODS}

Ten subjects (average age $24 \pm 2$ years, 9 females, 1 male) participated in the study. Participants were not previously diagnosed with any ocular diseases, and during the experiment they were corrected with the best spherocylindrical correction in a trial frame. Best corrected visual acuity and age distribution is showed in Table 1.

In order to exclude complications of the cycloplegic effect, a detailed anamnesis was collected, the angle of anterior chamber of eyeball was evaluated using the Van Herick technique, and intraocular pressure was measured for all participants (Pulsair intelliPuff non-contact tonometer by Keeler, Windsor, United Kingdom). Participants did not confirm any previous allergic reactions or other complications to the ophthalmic solution Cyclogyl $(10 \mathrm{mg} / \mathrm{ml}$ by Alcon-Couvreur N.V., Puurs, Belgium) that was used to cause paralysis of accommodation. None of the participants

Table 1

DESCRIPTION OF PARTICIPANTS' AGE AND BEST CORRECTED VISUAL ACUITY

\begin{tabular}{|c|c|c|c|}
\hline Participant & Age (y) & $\begin{array}{l}\text { Best spherocylindrical distance } \\
\text { correction }\end{array}$ & $\begin{array}{c}\text { Best visual } \\
\text { acuity } \\
\text { (decimal units) }\end{array}$ \\
\hline 1 & 24 & $-1.75 \mathrm{D} \mathrm{sph}$ & 2.0 \\
\hline 2 & 26 & planum sph & 2.0 \\
\hline 3 & 23 & planum sph $-1.00 \mathrm{D}$ cyl. ax. $105^{\circ}$ & 1.5 \\
\hline 4 & 23 & $-2.00 \mathrm{D} \mathrm{sph}$ & 1.2 \\
\hline 5 & 24 & $-0.75 \mathrm{D}$ sph $-0.50 \mathrm{D}$ cyl ax. $90^{\circ}$ & 1.5 \\
\hline 6 & 27 & $+0.50 \mathrm{D} \mathrm{sph}$ & 1.5 \\
\hline 7 & 23 & $-3.00 \mathrm{D}$ sph $-0.50 \mathrm{D}$ cyl ax. $50^{\circ}$ & 1.2 \\
\hline 8 & 18 & $+0.25 \mathrm{D}$ sph $-0.25 \mathrm{D}$ cyl ax. $180^{\circ}$ & 1.5 \\
\hline 9 & 23 & $-1.25 \mathrm{D}$ sph $-0.50 \mathrm{D}$ cyl ax. $155^{\circ}$ & 1.5 \\
\hline 10 & 24 & $-0.75 \mathrm{D}$ sph $-0.50 \mathrm{D}$ cyl ax. $105^{\circ}$ & 1.2 \\
\hline
\end{tabular}

had a narrow anterior chamber angle and intraocular pressure above $21 \mathrm{~mm} \mathrm{Hg}$.

Landolt rings with four possible directions of opening (up, down, left, and right) and a size of 6.25 minutes of arc (corresponding to a visual acuity table line of 0.8 in the decimal system or $0.1 \log$ MAR) were used to provide stimuli for measurements of blur perception thresholds. A Landolt ring was demonstrated five times in different positions for each blur level. Between each stimulus a gray uniform mask was demonstrated to avoid the detection of direction of Landolt ring opening by impression of ring's rotational movement.

The image processing filter "Gaussian blur" in the CorelDraw Graphics Suite X7 17.1.0.572 (Corel Corporation, Ottawa, Canada) software was used to provide various computer simulated blurring levels for Landolt rings. Stimuli were presented on a Lenovo Z50-70 (Lenovo Group Ltd., Beijing, China) computer screen (resolution $1920 \times 1080$ pixels) at $6 \mathrm{~m}$ distance from the participant. The "Gaussian blur" function in the programme is a low-pass spatial frequency filter. Gaussian blur disc diameter values for each blur level were recalculated from pixels to corresponding angular values. Blur level of the image increased with blur disc diameter value. This method can be considered as a "source method" of producing defocus, because the source of the visual image rather than the observer is defocused.

The experiment was conducted in scotopic lighting conditions (the only source of a light was the computer screen). Measurements were done in monocular conditions with subject's right eye open. An artificial pupil (4 mm, vertex distance $12 \mathrm{~mm}$ ) and ophthalmic lenses that provided best correction were placed in a trial frame in front of the participant's right eye and an occluder was placed in front of left eye during both conditions - with and without cycloplegia.

An ascending psychophysical method was used to determine individual subjective thresholds of the just noticeable blur and non-resolvable blur for all participants. Participants were asked to evaluate image quality and report just noticeable blur as blur level of an image was gradually increased from focused and clear image. The blur level continued to increase until the participant for first time could not correctly determine the direction of Landolt ring's opening for three times out of five demonstrations for a particular blur level (non-resolvable blur threshold). A descending psychophysical method was used to determine recognition and clear image thresholds. At the beginning of this stage of experiment, a Landolt ring image was blurred so that direction of the Landolt ring's opening was not detectable for the participant; the blur level was gradually decreased during the experiment. The recognition threshold was recorded when the participant for the first time correctly determined the direction of Landolt ring's opening at least three times out of five demonstrations for a particular blur level. The blur level continued to decrease until the participant evaluated the image as clear and focused (clear image threshold). Measurement of each threshold was repeated five times in 
conditions with and without cycloplegia. Experiment sessions with and without cycloplegia were held at least seven days apart. For half of the participants, the first session was conducted using cycloplegia, and for the other half of participants the first session was conducted without the use of cycloplegia, to avoid the effect of session order on the results of this research.

Experimental procedures and protocol were approved by the Research Ethics Commission of the Experimental and Clinical Medicine Institute (University of Latvia). All participants were informed of the experimental protocol and possible aftereffects and they gave their consent to participate in the research.

Microsoft Office Excel software (Microsoft Corporation, Redmond, Washington, USA) was used for data analysis and the Wilcoxon Signed-Rank non-parametric statistical test was used to determine statistical significance as data were non-normally distributed (Shapiro-Wilk test).

\section{RESULTS}

The amplitude from the lowest to highest threshold differed among participants, as well as the difference between participants for particular blur perception thresholds. For example, the threshold of just noticeable blur (without cycloplegia) was achieved at average blur disc diameter of 0.33 min of arc for participant A, compared to $1.97 \mathrm{~min}$ of arc for participant $\mathrm{H}$ at. Results of all blur perception thresholds are showed in Figure 1.

A statistically significant difference between just noticeable blur threshold and clear image threshold was observed in seven of ten participants $(Z=-2.80, p=0.005)$ without the use of cycloplegia and eight out of ten participants $(Z=$ $-2.80, p=0.005)$ with cycloplegia. However, for all participants the just noticeable blur threshold was lower than clear image threshold with and without the use of cycloplegia (see Fig. $1 \mathrm{~A}$ and B). This means that the observer perceives the image as clear when the descending method was used even if the same stimulus was reported as blurry during the application of the ascending method.

A statistically significant difference between non-resolvable blur threshold and image recognition threshold was observed only in four participants without the use of cycloplegia and in two participants with cycloplegia. The results suggest that the non-resolvable threshold is lower than the recognition threshold. Generally, the difference between just noticeable blur and clear image thresholds is greater than the difference between non-resolvable blur and recognition thresholds (see Fig. $1 \mathrm{~A}$ and B).

Comparison of conditions with and without cycloplegia for just noticeable blur, clear image, non-resolvable blur, and recognition threshold is demonstrated in Figure 2. Individual statistical analysis showed no significant difference in just noticeable blur threshold between both conditions for
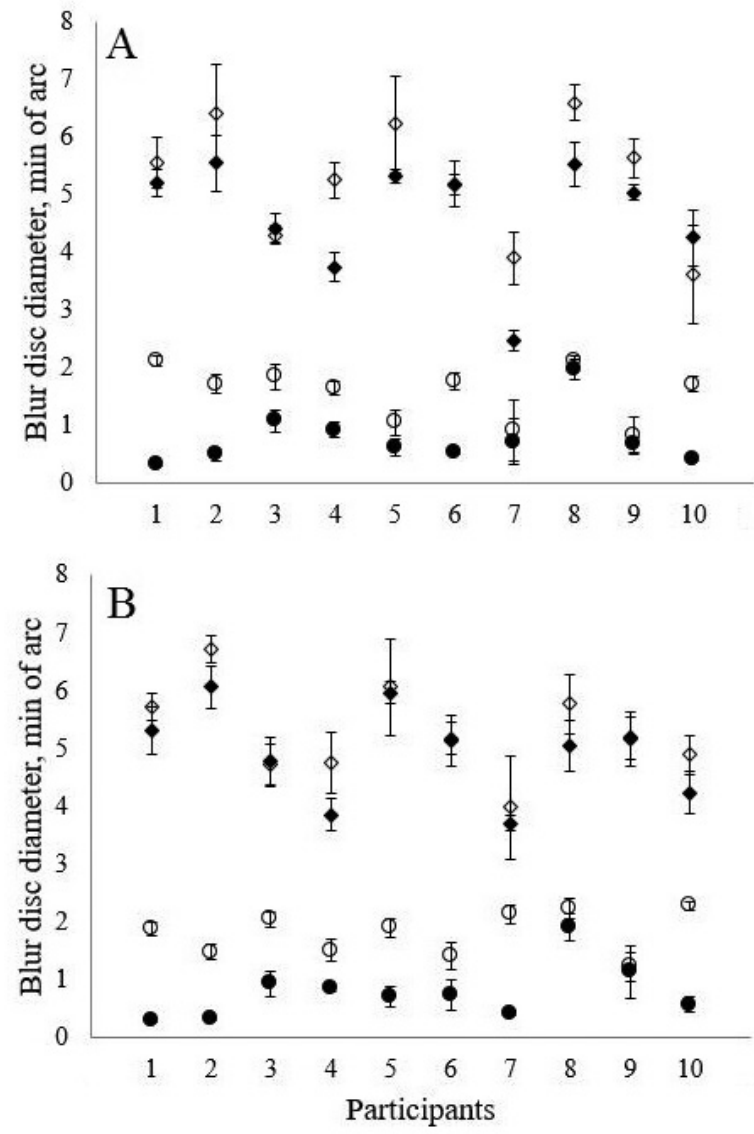

- Just noticeable blur o Clear image threshold - Non-resolvable blur $\diamond$ Recognition threshold
Fig. 1. Blur perception thresholds for all participants. A without cycloplegia, B - with cycloplegia. Circles represent thresholds determined by ascending method, diamonds represent thresholds determined by descending method $( \pm 1$ standard deviation is showed for each threshold) 

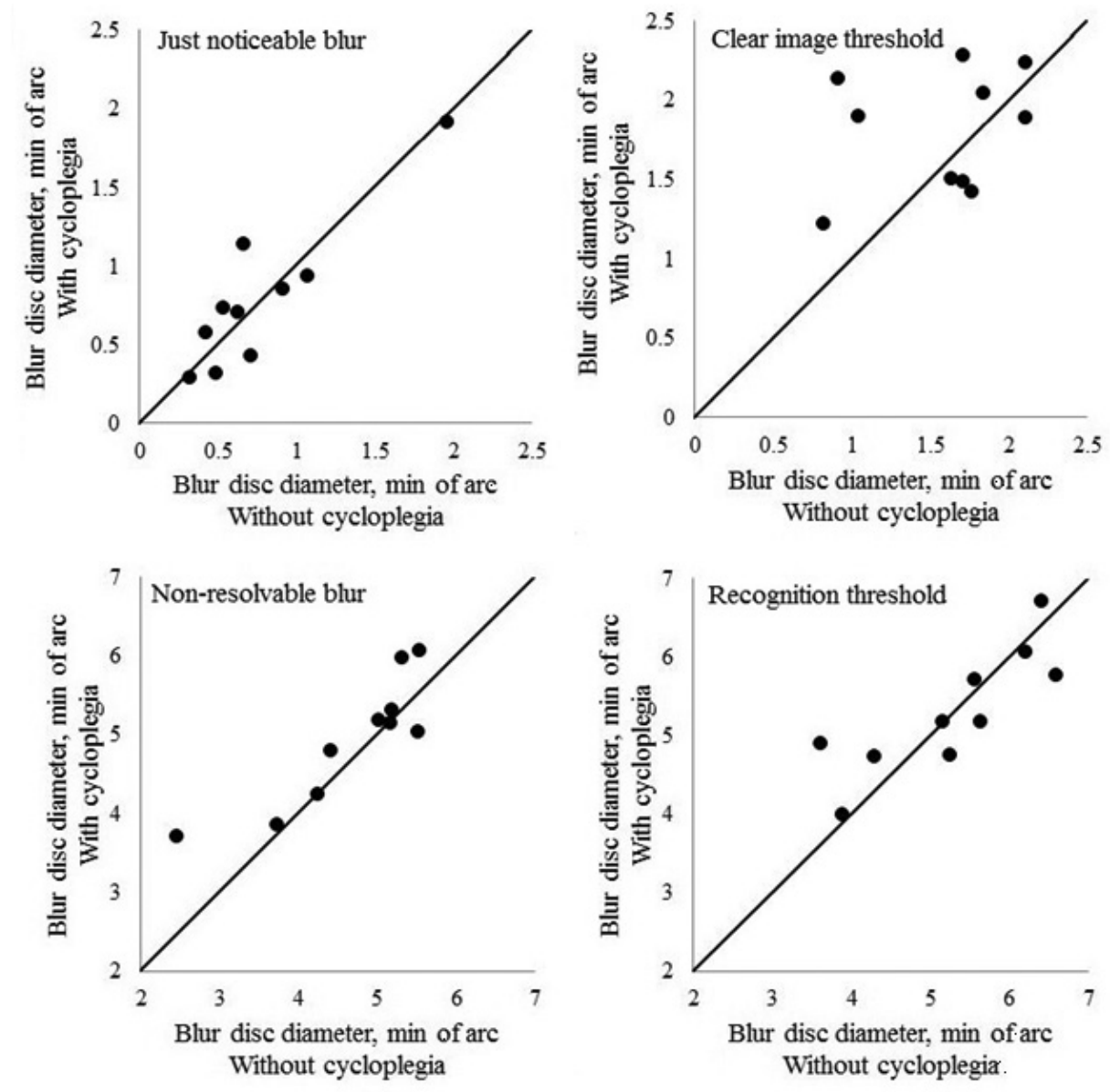

Fig. 2. A comparison of blur perception thresholds with and without use of cycloplegia just noticeable blur, clear image, non-resolvable blur and recognition threshold for all participants. Solid line represents unity. Points located above the solid line show an increase in threshold when cycloplegia was used. Points located below solid line show a decrease in threshold when cycloplegia was used.

nine of ten participants, and for four of ten participants in the clear image threshold. The Wilcoxon Signed-Rank Test showed no effect of cycloplegia on just noticeable blur $(Z=$ $-0.051, p=0.96)$ and clear image $(Z=-1.07, p=0.28)$ thresholds. The Wilcoxon Signed-Rank Test also showed no significant effect of cycloplegia on non-resolvable blur threshold $(Z=-1.78, p=0.075)$ and recognition threshold $(Z=-0.051, p=0.96)$.

\section{DISCUSSION}

Comparison of just noticeable blur and clear image thresholds both in conditions with and without cycloplegia showed that the threshold determined by the descending psychophysical method (a gradual blur level decrement) was higher than the threshold determined by the ascending psychophysical method - gradual blur level increment (see Fig. 3). Subjective evaluation of image quality depends on previous blur experience and adaptation (Mon-Williams et al., 1998; Webster et al., 2002; Khan et al., 2013). It was suggested (Mon-Williams et al., 1988) neuronal recalibration occurred, which involved spatial frequency sensitivity changes.

Short-term blur adaptation during this experiment may explain why clear image threshold and recognition threshold was higher than just noticeable blur threshold and non-resolvable blur threshold. The reference Landolt ring image in the descending method was significantly blurred and during the experimental session of 12 minutes (average time period for the participant from one threshold to another), the observer adapted to a defocused stimulus.

Non-resolvable blur and recognition thresholds were more similar than the just noticeable blur and the clear image thresholds Fig. 3). The main difference between the conditions in which these thresholds are reported is a marked blur level change - subjective judgement of just noticeable blur threshold and clear image threshold is made in relatively clear conditions (blur disc diameter on average 0-2.5 min of arc), while non-resolvable blur and recognition threshold

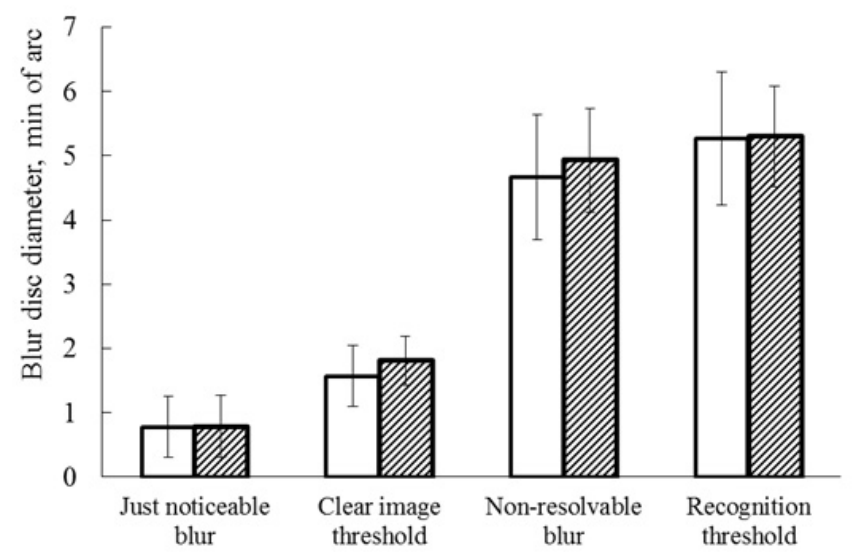

Fig. 3. A comparison of the mean values of blur perception thresholds with (striped) and without (white) use of cycloplegia ( \pm 1 standard deviation is showed for each threshold). 
are evaluated in considerably blurrier conditions (blur disc diameter on average 3-7 $\mathrm{min}$ of arc).

If we consider the time spent observing blurry stimuli during the descending phase of measurement as the blur adaption time, then blur perception thresholds have increased after blur adaptation. This observation is in contrast to a previous study of blur adaptation in myopes (Wang et al., 2006), where a decrease of 0.15-0.19 D was observed in noticeable, bothersome and non-resolvable blur thresholds after $1 \mathrm{~h}$ adaptation to a $+2.50 \mathrm{D}$ ophthalmic lens over observer's distance correction. According to our results, blur sensitivity increased after blur adaptation, however this does not explain the visual acuity improvement after blur adaptation that was observed in other studies (Cufflin et al., 2007; Khan et al., 2013; Poulere et al., 2013).

\section{CONCLUSIONS}

1. There was no evidence of cycloplegic effect on blur perception thresholds using both, ascending and descending methods, suggesting no need to use cycloplegia during measurements of blur perception with the source method.

2. Blur perception thresholds are individual, but for all participants the clear image threshold was higher than just noticeable blur threshold both, with and without cycloplegia. A statistically significant difference between these thresholds was observed in seven of ten participants.

3. There were no significant differences observed between thresholds of stimulus recognition and unrecognition with and without use of cycloplegia.

\section{ACKNOWLEDGEMENTS}

This work was supported by Department of Optometry and Vision Science, Faculty of Physics and Mathematics, University of Latvia.

\section{REFERENCES}

Atchison, D. A., Charman, W. N., Woods, R. L. (1997). Subjective depthof-focus of the eye. Optom. Vis. Sci., 74 (7), 511-520.
Atchison, D. A., Fisher, S. W., Pedersen, C. A., Ridall, P. G. (2005). Noticeable, troublesome and objectionable limits of blur. Vis. Res., 45 (15), 1967-1974.

Ciuffreda, K. J., Selenow, A., Wang, B., Vasudevan, B., Zikos, G., Ali, S. R. (2006). Brothersome blur: A functional unit of blur perception. Vis. Res., 46 (6-7), 89-901.

Cufflin, M. P., Hazel, C. A., Mallen, E. A. H. (2007). Static accommodative responses following adaptation to differential levels of blur. Ophthalmic Physiol. Optics, 27 (4), 353-360.

Cufflin, M. P., Mallen, E. A. H. (2008). Dynamic accommodation responses following adaptation to defocus. Optom. Vis. Sci., 85 (10), 982-991.

Cufflin, M. P., Manowska, A., Mallen, E. A. H. (2007). Effect of blur adaptation on blur sensitivity and discrimination in emmetropes and myopes. Investig. Ophthalmol. Vis. Sci., 48 (6), 2932-2939.

Dehnert, A., Bach, M., Heinrich, S. P. (2011). Subjective visual acuity with simulated defocus. Ophthalmic Physiol. Optics, 31 (6), 625-631.

Jacobs, R. J., Smith, G., Chan, C. D. C. (1989). Effect of defocus on blur thresholds and on thresholds of perceived change in blur: Comparison of source and observer methods. Optom. Vis. Sci., 66 (8), 545-553.

Khan, K. A., Dawson, K., Manowska, A., Cufflin, M. P., Mallen, E. A. H. (2013). The time course of blur adaptation in emmetropes and myopes. Ophthalmic Physiol. Optics, 33 (3), 305-310.

Le, R., Bao, J., Chen, D., He, J.C., Lu, F. (2010). The effect of blur adaptation on accommodative response and pupil size during reading. J. Vis., 10 (14), $1-12$.

Mon-Williams, M., Tresilian J. R., Strang, N. C., Kochhar, P., Wann, J. P. (1998). Improving vision: neural compensation for optical defocus. Proc. Royal Soc. B: Biol. Sci., 265 (1390), 71-77.

Poulere, E., Moschandreas, J., Kontadakis, G. A., Pallikaris, I. G., Plainis, S. (2013). Effect of blur and subsequent adaptation on visual acuity using letter and Landolt $\mathrm{C}$ charts: Differences between emmetropes and myopes. Ophthalmic Physiol. Optics, 33 (2), 130-137.

Smith, G., Jacobs, R. J., Chan, C. D. C. (1989). Effect of defocus on visual acuity as measured by source and observer methods. Optom. Vis. Sci., 66 (7), 430-435.

Vera-Diaz, F. A., Gwiazda, J., Thorn, F., Held, R. (2004). Increased accommodation following adaptation to image blur in myopes. J. Vis., 4 (12), 1111-1119.

Wang, B., Ciuffreda, K. J. (2005a). Blur discrimination of the human eye in the near retinal periphery. Optom. Vis. Sci., 82 (1), 52-58.

Wang, B., Ciuffreda, K. J. (2005b). Foveal blur discrimination of the human eye. Ophthalmic Physiol. Optics, 25 (1), 45-51.

Wang, B., Ciuffreda, K. J., Vasudevan, B. (2006). Effect of blur adaptation on blur sensitivity in myopes. Vis. Res., 46 (21), 3634-3641.

Webster, M. A., Georgeson, M. A., Webster, S. M. (2002). Neural adjustments to image blur. Nature Neurosci., 5 (9), 839-840.

Received 2 October 2016

Accepted in the final form 28 July 2017

\section{CIKLOPLĒGTIJAS IETEKME UZ APMIGLOJUMA UZTVERES SLIEKŠN̦IEM, KAS NOTEIKTI AR AVOTA METODI}

Viena no avota apmiglošanas metodes priekšrocībām salīdzinājumā ar novērotāja apmiglošanas metodi ir labāka stimula apmiglojuma līmeṇa kontrole, ko nodrošina datorizēta attēla apstrāde. Novērotāja apmiglošanas metodes gadījumā nepieciešama optiska defokusācija. Šī pētījuma mērkis bija noskaidrot, vai akomodācijas darbības apturěšana atstāj iespaidu uz apmiglojuma uztveres sliekšṇu noteikšanu, tādējādi novērtējot, vai cikloplēǵija (akomodācijas darbības medikamentoza apturēšana) ir absolūti nepieciešama līdzīgu pētījumu veikšanā. Apmiglojuma uztveres sliekšni (tikko pamanāmā apmiglojuma, skaidra attēla uztveres, objekta atpazī̌anas un neatpazišanas sliekšṇi) tika noteikti gan cikloplēégijas apstākḷos, gan bez tās, lai novērtētu, vai tā atstāj nozīmīgu iespaidu uz apmiglojuma uztveri. Datorizēts zemo telpisko frekvenču filtrs tika izmantots, lai apstrādātu Landolta gredzena attēlus un radītu pakāpenisku apmiglojuma līmeņa palielināšanos no skaidra attēla līdz brīdim, kad nav iespējams pareizi noteikt Landolta gredzena atvēruma virzienu. Ascendējošā un descendējošāā psihofizikālā trepjveida metode tika pielietota, lai noteiktu iepriekš minētos apmiglojuma uztveres sliekšņus. Desmit dalībnieku uzrādītie rezultāti atklāja, ka nav novērojama būtiska cikloplēǵijas ietekme uz apmiglojuma uztveres mērījumiem, kas veikti ar avota apmiglošanas metodi, līdz ar to var secināt, ka mērījumus ar avota metodi var veikt bez cikloplēǵijas pielietošanas. 